\title{
A NOVA TITULAR, PROFESSORA MARIA SYLVIA ZANELLA DI PIETRO, PROFERE SEU DISCURSO DE POSSE
}

As palavras que hoje lhes dirijo certamente não são as mesmas que teria dito há quase três anos passados, no dia em que, dentre quatro candidatos, fui indicada para ocupar, com muito orgulho, a vaga deixada pelo professor José Cretella Júnior. Hoje são outros os sentimentos. Àquela época seria a paixão e a embriaguez momentânea de uma vitória. Hoje é a emoção serena e segura de uma vitória muitas vezes confirmada e revivida.

As barreiras a mais que foram colocadas em um caminho já por si repleto de dificuldades, eu tive que derrubá-las uma a uma. E isto transformou uma vitória em muitas vitórias e me deu o ensejo de vivê-las, saboreá-las, amadurecêlas, até poder perceber que a vitória-maior, proclamada no dia 16 de agosto de 1991, eu a vinha conquistando há muito tempo. Pois essa não é uma batalha que se vence num dia; ela é fruto de toda uma existência; ela é fruto de um modo de pensar e de sentir; ela é fruto do amor ao desafio que, em algum momento de minha vida, começou a florescer de mansinho, cresceu e formou profundas raízes que me deram a força, a determinação, a vontade de vencer todas as barreiras que eram infinitamente grandes para uma criança e uma adolescente que a natureza fizera excessivamente dotada de inibições e de temores. Só os que acompanharam o seu crescimento podem avaliar o contraste entre o que aquela criança e adolescente eram e a pessoa que hoje ela é, e entender a enormidade do desafio e, portanto, a enormidade da vitória.

Vencer cada uma das muitas etapas da carreira universitária, significou para aquela jovem, vencer passo a passo uma luta com o seu próprio eu. E essa é uma luta solitária, porque vivida no mais íntimo de nosso ser. Essa solidão na luta acostumou-me a contar com minhas próprias armas, sem jamais pedir ou implorar favores, privilégios, concessões, favorecimentos, seja em nome da amizade ou da justiça. Jamais pedi ajuda para ganhar as minhas batalhas. E disto podem dar testemunho, sem qualquer exceção, todos os que nesta Congregação, ou fora dela, participaram das decisões e julgamentos que consagraram em definitivo a minha vitória. Recebi-a como uma dádiva e uma recompensa pelos meus esforços. Jamais poderia aceitá-la de outro modo porque, nascida embora na simplicidade de um 
berço de rica menina pobre, não aprendi a contentar-me com migalhas, migalhas de uma vitória que acaso, por direito a outrem pertencesse.

A solidão na luta faz parte de meus principios e de meu modo de viver. Por isso mesmo todas as dificuldades encontradas a mais pelo caminho não foram mais do que pequenos obstáculos que pude transpor com muita serenidade, porque a vitória-maior eu já a vencera há muito tempo.

Ter a oportunidade de muitas vezes confirmá-la e revivê-la tem sido uma grande alegria. E esta alegria hoje se renova. E se renova porque posso compartilhá-la com todos aqueles que testemunharam as minhas lutas e conquistas. Tanto sou devedora dos que contribuíram para tornar mais renhidas as lutas, como dos que espontaneamente me ajudaram a vencê-las, dando-me um pouco de sua lealdade, amizade, conforto.

Fui acumulando, no decurso do tempo, uma enorme bagagem, que me foi sendo distribuida por familiares e amigos e enriquecida, a cada passo, pelos inúmeros mestres que, nos vários níveis de vida escolar, deram a sua parcela de contribuição para formar aquela que hoje é solenemente recebida, depois de tanto tempo, como Professora Titular da Faculdade de Direito da Universidade de São Paulo.

Fui premiada com excelentes mestres. Porém, se me fosse dado, neste momento, o dom de retratar, pela pintura, escultura ou poesia, a figura ideal de um professor, a emoção e a gratidão que hoje sinto certamente me levariam a retratar a imagem de minha mãe. Não porque ela me tenha dado a vida e me ensinado as primeiras lições de vida. Mas porque tive a felicidade de tê-la não só como mãe, mas como mestra em três anos do então chamado grupo escolar. E ainda porque nela existe um grande senso natural de justiça que certamente inspirou em mim o amor pelo Direito.

Confundia-se, nela, o papel de mãe e professora e, em mim, o de filha e aluna.

Com ela aprendi a andar, a falar, a crescer. Mas também com ela aprendi a ler e a escrever; a somar, diminuir, multiplicar e dividir; dela ouvi as primeiras narrativas sobre a História do Brasil e do Mundo; dela ouvi as primeiras poesias. Com ela aprendi a orar, a ter fé em Deus e nos homens, a respeitar o ser humano sem qualquer distinção de cor, raça ou classe social. Com ela aprendi, não sei se como mãe ou professora, que saber distinguir o valor do "sim" e do "não", do 
certo e do errado, do honesto e do desonesto designa firmeza de princípios que fazem a dignidade e a grandeza do homem.

Por seu senso natural de justiça e retidão, apregoou o velho adágio que manda dar a César o que é de César e a Deus o que é de Deus; também ensinou que fazer o bem sem olhar a quem seus perigos tem e Deus ajuda quem se ajuda, fazendo entender o valor do esforço pessoal para a vitória.

Dela recebi as primeiras notas e avaliações. Com ela aprendi a competir com minhas irmãs e com meus colegas de escola; entendi que nem sempre somos os primeiros; que a derrota deve ser recebida com dignidade e, a vitória, com humildade.

Talvez por tudo isso se confundam em minha lembrança as idéias de lar e de escola; de mãe e de professora; de ensinar e de amar; de aprender e de compartilhar.

A bagagem que ela me entregou foi a mais valiosa; não sei se consegui reter tudo pelo caminho. Certamente muita coisa se perdeu. Mas muita coisa também se acrescentou pela convivência com um pai amoroso dotado dos muitos dons que fazem a alegria da família; pela união duradoura com um companheiro incansável e inseparável que, com seu amor, tornou mais brandos os embates da vida; pela convivência com os colegas e amigos da Procuradoria Geral do Estado e da Consultoria Jurídica da Universidade de São Paulo, onde fui encontrar novo tipo de aprendizado, pela experiência que se adquire no dia-a-dia e permite tornar mais viva a doutrina que se ensina na escola; pela convivência com familiares e amigos que, de alguma forma, contribuiram para me dar a força, a vontade e a coragem de percorrer o difícil caminho que escolhi; pelo contato com os alunos, que nos emprestam constantemente a alegria e a força de sua juventude. Muitos dos entes que amei e que em mim depositaram uma fé inabalável não estão mais entre nós, porém deixaram a doce lembrança de sua presença, que permanece viva de muitos modos, com muita saudade, e ainda inspira, muitas vezes, as melhores atitudes diante das asperezas da vida. A todos homenageio, presentes e ausentes, na pessoa de minhha mãe, por ser ela o símbolo de tudo o que tem sido bom e sublime em minha vida.

$O$ certo é que foi com a bagagem que dela recebi, enriquecida pelos anos da juventude, a juventude dos anos dourados, que cheguei às portas desta Academia. Amei-a à primeira vista; amei a magia que se desprende das tão famosas Arcadas, inspiradoras de tantos versos, cânticos e poesias; amei a nobreza de estilo 
do artista que a concebeu; amei a história que ela encerra e que parece destacar-se de suas escadarias, de seus vitrais, de suas salas de aula, para impregnar-se em nossas almas e nos impulsionar na busca do Direito e da Justiça; amei o futuro que ela me abria sem ter plena consciência do destino a que me levava e de que grande parte de minha vida, de minhas lutas, derrotas e conquistas, iria desenvolver-se dentro dela. Tive a felicidade de, em relação a ela, sentir bater no peito a heróica pancada.

Desfilam hoje pela minha lembrança os mestres que me ensinaram. De todos guardo as melhores lembranças. De alguns sou hoje colega de magistério e amiga. A todos homenageio. Mas homenageio especialmente alguns que desempenharam marcante papel em momentos dificeis de minha vida. Homenageio a generosidade, a espontaneidade, o desprendimento, a coragem, que levaram o professor José Ignácio Botelho de Mesquita, por apego a seus próprios princípios e valores, quando tantos se calaram, a levantar a sua voz respeitável perante a Congregação desta Faculdade, juntamente com o professor Eros Roberto Grau, em defesa da validade do concurso que me colocou no ápice de tão árdua quanto bela carreira universitária; homenageio a perseverança e a dedicação do professor José Cretella Júnior na orientação segura e incansável em todas as fases de minha carreira; e homenageio a confiança incondicionada que em mim depositou o professor Dalmo de Abreu Dallari que, por acreditar no talento da aluna, estendeu a mão para ajudá-la a transformar-se em professora. Por sua mão amiga, fui levada a ministrar as primeiras aulas nesta Faculdade, na disciplina de Teoria Geral do Estado; esteve presente em todas as bancas que enfrentei, no mestrado, doutorado, concurso de ingresso, livre-docência e titular, sem que em nenhum momento permitisse que os longos anos de cordial convivência interferissem na seriedade e no brilho de suas argüições.

Tem sido um longo e dificil caminho. Desde que pela primeira vez ingressei no pátio desta Academia, não me lembro de nenhuma fase de minha vida que não fosse de muito estudo, infindáveis horas de leitura e de pesquisa, de trabalho incansável. Sempre repito para meus alunos que sonham com o magistério de nível superior, que não basta sonhar; é preciso ter vocação para o estudo. Sei hoje que é preciso muito mais do que isso para enfrentar aquela que é, incontestavelmente, uma das mais espiņhosas e sacrificadas carreiras de nivel universitário; ela se desenvolve em muitas etapas; exige muita perseverança; ela testa a grandeza de nossos princípios, quando nos coloca em competição com outros 
parceiros que acalentam os mesmos sonhos e enfrentam as mesmas batalhas, das quais, muitas vezes, apenas um pode sair vencedor; ela nos coloca em permanente contato com a juventude, que é exigente, porque quer aprender, quer ser amada, quer ser respeitada, quer ser ouvida

E ensinar o Direito, transmitir as noções de legalidade, igualdade e justiça, em um país de contrastes como o nosso, não constitui tarefa fácil. Rui Barbosa, há muitas décadas, descrevia o Brasil como "um mundo completo no âmbito de suas fronteiras, com todas as zonas, todos os climas, todas as constituições geológicas, todos os relevos do solo, uma natureza adaptável a todos os costumes, a todas as fases da civilização, a todos os ramos de atividade humana, um meio fisico e um meio moral varióvel na mais indefinida escala"

O que diria Rui Barbosa se visse hoje os incomensuráveis contrastes sociais que testemunhamos e parecem ter resultado, em grande parte, daquela mesma diversidade por ele tão lindamente descrita? O que diria hoje se fosse, em outra Oração aos Moços, dirigir-se mais uma vez aos jovens desta velha e sempre nova Academia? Talvez apenas repetisse os seus velhos e sempre novos ensinamentos. E talvez pudesse nos dizer qual a melhor forma de explicar ao jovem, diante da realidade à nossa volta, por que o preâmbulo da nossa Constituição afirma, com majestosas palavras, que o Brasil é uma sociedade fraterna, pluralista e sem preconceitos; e que os representantes do povo brasileiro, ao se reunirem em Assembléia Constituinte, tinham por objetivo instituir um Estado democrático, destinado a assegurar a liberdade, a segurança, o bem-estar, o desenvolvimento, a igualdade e a justiça; como explicar a afirmação de princípios como o da dignidade da pessoa humana, da erradicação da pobreza e da marginalização, da redução das desigualdades sociais e regionais, quando é exatamente o contrário que acontece? Como explicar que o princípio da legalidade exige submissão à lei de todos os Poderes instituídos? E o princípio da moralidade administrativa? Como dizer ao jovem que todos esses valores estão contidos de forma expressa na lei fundamental que rege a vida deste país e não de outro qualquer?

Será que tudo isto foi posto na Constituição por esses mesmos parlamentares que hoje nos deixam atônitos e estarrecidos com tanta corrupção, desrespeito à lei, à moral, à pobreza e à dignidade do povo brasileiro? Será que, ao redigirem a Constituição, estavam pensando na realidade do nosso país ou em algum país do mundo dos sonhos? 
Talvez não.

Quero crer que a sua intenção fosse a melhor possível e que da elaboração da Constituição também participaram pessoas honestas, leais, que sonham com o Brasil que descreveram; e que, na cabeça do jovem, as palavras da Constituição, independentes de quem as redigiu, ficarão como um ideal a ser atingido, servindo de inspiração e de norte em suas vidas.

Quero crer que a dignidade do homem comum supera a do homem público e que é o senso de justiça, inerente ao ser humano, que leva o jovem universitário a exigir diálogo com os docentes, a pedir revisão de provas, a querer participar ativamente dos órgãos de administração da Universidade, a querer eleições diretas para Reitor, a querer respostas a todas as suas dúvidas, angústias e anseios. A querer, enfim, participar.

Quero crer que o jovem estudante tem o espírito de justiça e o patriotismo que se espera dos que almejam o desenvolvimento, o bem-estar, a justiça, a igualdade, a vitória.

Quero crer que ele sabe o que quer e luta por isso quando sai às ruas clamando pelas "diretas já" ou quando, como "cara pintada" grita até ser ouvido, entendido e atendido, ou quando se mistura ao povo, sofrido, de bandeira em punho, para chorar a perda de seu herói como se chorasse a perda de um pedacinho de seu próprio ser.

Momentos como esse constituem espetáculos de rara beleza, talvez porque expressem o sentimento daquilo que se chama nação; ou, quem sabe, porque simbolizem a voz única de um povo que, momentaneamente, desperta, olha à sua volta, supera as diferenças de raça, de religião, de cor, de partido político, de classe social, para transformar, por vezes, governantes em governados e impor-lhes a força de sua vontade incontrastável.

Um povo que assim se expressa merece a nossa crença e a nossa luta. Merece que cultivemos a esperança de que a nossa realidade estará um dia muito mais próxima dos valores que o constituinte brasileiro idealizou para uma sociedade fraterna, pluralista e sem preconceitos. Merece que repensemos as nossas instituições, a nossa sociedade, o nosso Estado, o nosso Direito, na busca incansável do bem-comum.

Eu acredito nos jovens, porque convivo com eles e sinto a sua revolta contra as situações que eles sabem ser injustas. Confesso, é verdade, que sinto às vezes certo constrangimento ao tentar transmitir alguns princípios e valores que a 
Constituição dirige ao administrador público, tão grande é o contraste da lei com a realidade. Mas, por acreditar no jovem, no homem comum do povo, tento manter viva dentro de mim a esperança de viver para ver um Brasil melhor.

Não gostaria de chegar ao desencanto com que Padre Antônio Vieira, cansado de falar aos homens, resolveu escrever o seu sermão aos peixes; ou às palavras tão belas quanto amargas com que Vicente de Carvalho descreveu a existência, resumida, como uma "grande esperança malograda" dizendo que a felicidade existe sim, mas nós não a alcançamos porque está sempre "apenas onde a pomos e nunca a pomos onde nós estamos"

Prefiro as palavras dos que têm fé e esperança, porque quero manter viva em mim a força que me compeliu para uma batalha de que saí muitas vezes vitoriosa. Quero manter viva a crença no povo brasileiro e na sua capacidade de colocar a felicidade onde realmente estamos; quero manter viva a coragem para enfrentar o desafio de entregar ao jovem um pouco daquela bagagem que acumulei ao longo dos anos, fazendo com que também para ele esta Escola tenha um pouco de seu lar e que o aprender seja também amar e compartilhar um pouco da luta por uma sociedade mais justa, mais digna e mais próxima do mundo dos nossos sonhos.

Concluo fazendo minhas por não poder fazer mais belas - as palavras com que Guilherme de Almeida, o poeta paulista formado por esta Faculdade, fez a sua prece a Anchieta descrevendo-o como aquele que, como Santo, ergueu a "cruz na selva escura"; como Herói, plantou "a nossa velha aldeia"; como Mestre, ensinou a "doutrina pura" e, como Poeta, escreveu "versos sobre a areia".

"Santo, herói, mestre e poeta. - Pela glória

que destes a esta Terra e a sua História,

Pela dor que sofremos sempre nós.

Pelo bem que quisestes a este povo,

O novo Cristo deste Mundo Novo,

Padre José de Anchieta, orai por nós." 